\title{
PENGGUNAAN BAHASA DALAM PERSPEKTIF TINDAK TUTUR DAN IMPLIKASINYA BAGI PENDIDIKAN LITERASI
}

\author{
Eka Haryanti \\ Fakultas Teknik, Universitas Teknologi Sumbawa \\ Email: ekaharyanti.uts@gmail.com
}

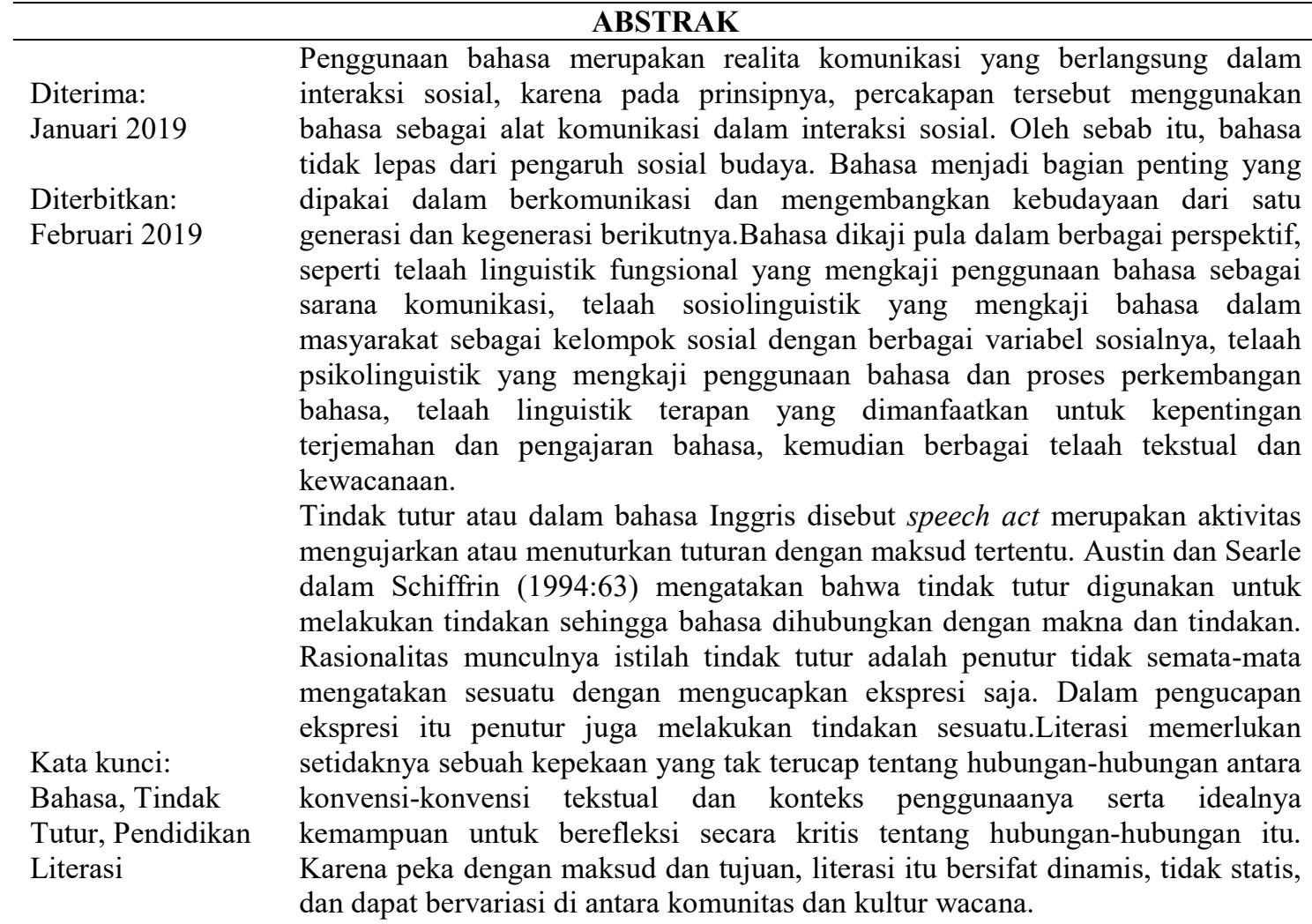

\section{PENDAHULUAN}

Bahasa Indonesia hanya satu dari sekitar 6.700 buah bahasa di dunia. Bahasa-bahasa di dunia berkembang dari satu bahasa yang dibawa oleh nabi Adam A.S. dan Siti Hawa sebagai sepasang manusia pertama. Sebagaimana disebutkan Al Quran bahwa setiap nabi diutus oleh Allah SWT membawa ajaran Tuhan ke bumi. Ajaran untuk menyampaikan misi Tuhan dalam memakmurkan bumi. Pada konteks ini, bahasa menjadi bagian penting yang dipakai dalam berkomunikasi dan mengembangkan kebudayaan dari satu generasi dan kegenerasi berikutnya. Menurut Ambri (dalam Zahari, 2011) menyebutkan bahwa asal usul bahasa di dunia ini terdiri atas empat rumpun. Salah satu dari rumpun itu adalah rumpun Asutria yang kemudian digolongkan menjadi dua bagian, yakni: bahasa Austronesia (Austronesia sebelah Barat dan sebelah Timur). Dan bahasa Melayu menjadi bagian dari rumpun bahasa Austronesia sebelah
Barat. Karena berbagai faktor, dalam perkembangannya bahasa Melayu menjelma menjadi bahasa Nasional Republik Indonesia, Malaysia, dan Brunei Darussalam

Bangsa Indonesia sebagai bangsa yang merdeka, telah memperjuangkan kemerdekaannya sendiri, diperjuangkan oleh seluruh rakyat Indonesia. Dengan semangat cinta tanah air, seluruh elemen rakyat Indonesia telah merebut kemerdekaannya dari cengkraman bangsa penjajah. Bahasa Indonesia adalah salah satu bukti yang menunjukkan bahwa Indonesia adalah bangsa yang merdeka, yang menciptakan bahasanya sendiri berdasarkan kesepakatan seluruh lapisan masyarakat melalui momentum Sumpah Pemuda tahun 1928. Bahasa itulah yang digunakan sebagai alat komunikasi yang dipakai oleh seluruh orang yang menempati wilayah Negara kesatuan Republik Indonesia.

Dasar hukum dalam membina dan pengembangan bahasa Indonesia adalah Undang- 


\section{JURNAL TAMBORA}

Vol. 3 No. 1 Februari 2019

undang Dasar Negara Tahun 1945. Undang-undang nomor 25 tahun 2009 tentang bendera, bahasa, dan lambing Negara, serta lagu kebangsaan. Terdapat pada pasal 29, ayat (1) "Bahasa Indonesia wajib digunakan sebagai bahasa pengantar dalam pendidikan". Terdapat pula pada pasal 33 ayat (1) "Bahasa Indonesia wajib digunakan dalam komunikasi resmi di lingkungan kerja pemerintah dan swasta". Bahasa menjadi alat utama untuk menjadikan manusia sebagai makhluk sosial yang dapat berkomunikasi dengan manusia lainnya.

Penggunaan bahasa merupakan realita komunikasi yang berlangsung dalam interaksi sosial, karena pada prinsipnya, percakapan tersebut menggunakan bahasa sebagai alat komunikasi dalam interaksi sosial. Oleh sebab itu, bahasa tidak lepas dari pengaruh sosial budaya. Hal ini sesuai dengan pandangan fungsional terhadap bahasa sebagai sistem tanda tidak terlepas dari faktor eksternal, yaitu ciri sosial, ciri demografi, dan sebagainya dan fungsi bahasa tidak saja untuk komunikasi, tetapi juga menunjukkan identitas sosial bahkan budaya pemakainya (Brown dan Yule, 1996:1-4). Berdasarkan pandangan tersebut, penggunaan bahasa merupakan fenomena sosial dan budaya yang tidak terlepas dari tradisi berbahasa penuturnya. Hal itu dibenarkan oleh Brown (2007:6) karena dalam berbahasa tiap pelaku tutur senantiasa dilatari oleh faktor sosial dan nilai budaya dan tradisi di sekitarnya. Kebiasaan dapat bervariasi pada satu tempat dengan tempat lain, antara satu bangsa dengan bangsa lain.

Penggunaan bahasa ditandai oleh adanya hubungan antara penutur dan mitra tutur bahwa berkomunikasi itu merupakan hubungan antara penutur sebagai pemberi pesan dan mitra tutur sebagai penerima pesan. Sebagai alat komunikasi dalam interaksi sosial, bahasa mempunyai berbagai fungsi. Brown dan Yule (1996:1-4) mengemukakan bahwa secara umum fungsi bahasa itu dapat dilihat dari dua pandangan, yakni (1) pandangan transaksional, (2) pandangan interaksional. Kedua fungsi ini sangat penting karena berhubungan dengan penggunaan bahasa dalam proses sosial di dalam masyarakat.

Sesuai dengan pandangan Brown dan Yule tersebut, pemakaian bahasa dalam interaksi tidak dapat dilepaskan dari fungsi bahasa dan komponenkomponen interaksional yang lain. Keberhasilan penggunaan bahasa sebagai sarana interaksi dengan fungsi tersebut dipengaruhi oleh faktor pelaku tutur dan konteks yang mendasarinya. Oleh sebab itu, pemakaian bahasa dapat dipandang sebagai sistem yang di dalamnya melibatkan komponen kebahasaan, pelaku tutur, dan kebudayaan. Dengan kata lain, penggunaan berbahasa senantiasa dipengaruhi oleh komponen kebahasaan, hal-hal yang berkaitan dengan pelaku tutur, dan faktor sosial budaya.
Penggunaan bahasa pada percakapan dalam pembelajaran di kelas menarik untuk dipahami. Sesuai dengan pandangan fungsional terhadap bahasa, untuk memahami penggunaan bahasa dapat dilakukan dengan memandang percakapan sebagai peristiwa komunikasi atau peristiwa tutur bersemuka. Peristiwa komunikasi itu ditandai oleh percakapan antara penutur dan mitra tutur yang bersifat resiprokal bersemuka yang bentuknya ditentukan oleh tujuan sosial (Richard, 1995:5). Dalam mengkaji pemakaian bahasa penutur dan mitra tutur pada percakapan dalam sebuah situasi, tuturan dapat dipandang sebagai tindak tutur dan harus ditempatkan dalam keseluruhan konteks peristiwa tutur sesuai dengan konteks sosial budaya.

\section{PEMBAHASAN}

\section{Konsep Dasar Penggunaan Bahasa}

Bahasa sebagai sistem lambang bunyi yang dihasilkan oleh alat ucap manusia adalah fenomena alamiah, tetapi bahasa sebagai alat interaksi sosial di dalam masyarakat manusia adalah merupakan fenomena sosial. Hal ini sesuai dengan gagasan de Saussure yang mengacu pada konsep Durheim bahwa fakta sosial dapat dipandang sebagai obyek kajian (Dineen, 1967: 193-195). Gagasan de Saussure menjadi dasar acuan bagi kajian sistem internal bahasa secara sinkronis yang dilakukan oleh para linguistik strukturalis. Dalam waktu yang relatif singkat, ilmu bahasa sebagai suatu disiplin sendiri berkembang dengan pesat, dan kajian pada sistem internal bahasa dilakukan pada tataran fonologi (bunyi), morfologi (kata), sintaksis (frasa dan kalimat), dan semantik (makna). Kajian seperti yang dilakukan Bloomfield di tahun 1930-an dan Chomsky pada tahun 1957 berikut pengikut mereka menelaah kaidah kebahasaan dengan mendekonstruksi bahasa lepas dari konteks situasinya.

Sementara itu bahasa dikaji pula dalam berbagai perspektif, seperti telaah linguistik fungsional yang mengkaji penggunaan bahasa sebagai sarana komunikasi, telaah sosiolinguistik yang mengkaji bahasa dalam masyarakat sebagai kelompok sosial dengan berbagai variabel sosialnya, telaah psikolinguistik yang mengkaji penggunaan bahasa dan proses perkembangan bahasa, telaah linguistik terapan yang dimanfaatkan untuk kepentingan terjemahan dan pengajaran bahasa, kemudian berbagai telaah tekstual dan kewacanaan.

Manusia merupakan makhluk sosial dan perlu berinteraksi dengan sesamanya. Sarana utama dalam berinteraksi itu adalah melalui bahasa. Bahasa itu hidup selagi masih ada penuturnya, karena bahasa dipergunakan untuk mengkomunikasikan berbagai gagasan, perasaan dan keinginan. Dengan kata lain, ketika berkomunikasi manusia menggunakan bahasanya 
JURNAL TAMBORA

Vol. 3 No. 1 Februari 2019

untuk berbagai fungsi, seperti untuk menyampaikan informasi, bertanya, menyuruh, memberi apresiasi, menyatakan kekecewaan, dan sebagainya.

Bahasa tidak dapat dipisahkan dari kebudayaan, sebab hubungan antara keduanya sangat erat. Bahasa menyatu dengan orang yang menggunakannya dan memilikinya. Karena bahasa berkembang sesuai dengan kebutuhan dan karakteristik kebudayaan, maka setiap bahasa merefleksikan kebudayaan masyarakat pemakainya. Bahasa merupakan bagian dari sistem nilai, kebiasaan, dan keyakinan yang kompleks yang membentuk suatu kebudayaan. Bahasa merupakan salah satu bentuk perilaku kebudayaan, oleh sebab itu bahasa mudah dipahami dan digunakan sesuai dengan standar yang disepakati dan diikuti oleh kelompok masyarakat tertentu.

Salah satu konsep dasar penggunaan bahasa adalah wacana dalam komunikasi baik lisan maupun tulisan. Penggunaan bahasa dapat berupa percakapan, diskusi, tanya jawab, dan sebagainya. Penggunaan bahasa yang demikian itu ada dalam situasi komunikasi. Situasi komunikasi melibatkan beberapa komponen berupa penyampaian pesan yang dapat berupa pembicara atau penulis, penerima pesan berupa pendengar atau pembaca. Makna pesan atau kode merupakan lambanglambang kebahasaan, sedangkan saluran berupa sarana, dan konteks mencakup segala hal yang ada dalam peristiwa komunikasi. Penggunaan bahasa dalam komunikasi pasti disertai dengan konteks. Karena itu, salah satu titik perhatian analisis wacana adalah teks dan konteks (Sobur, 2002:56). Konteks dapat disebut sebagai sesuatu yang mengelilingi atau meliputi penggunaan bahasa.

Analisis wacana melakukan suatu penyelidikan untuk apa bahasa itu digunakan (Brown dan Yule, 1983:1). Hal ini menunjukkan adanya arah kajian pada penggunaan bahasa atau realitas bagaimana bahasa digunakan dalam kehidupan sehari-hari. Paradigma terhadap wacana, berpijak pada pendekatan struktural (formalis) dan fungsionalis. Kedua pendekatan ini tentu memiliki pandangan sendiri yang memiliki dasar pijakan yang kuat dalam memandang dan menyikapi bahasa, termasuk dalam lingkup wacana. Hal ini dapat kita cermati seperti yang dikemukakan oleh Hymes (1974b dalam Schiffrin, 1994:25) sebagai berikut:

\begin{tabular}{|l|l|l|l|}
\hline STRUKTURAL & & FUNGSIONAL \\
\hline 1. & $\begin{array}{l}\text { Struktur bahasa } \\
\text { (kode) sebagai } \\
\text { tata bahasa. }\end{array}$ & 1. & $\begin{array}{l}\text { Struktur } \\
\text { merupakan } \\
\text { (tindak, peristiwa) } \\
\text { tuturannya, yaitu } \\
\text { cara bertutur. }\end{array}$ \\
\hline 2 & $\begin{array}{l}\text { Penggunaan hanya } \\
\text { bahasa alat, } \\
\text { sebagai hal } \\
\text { mungkin } \\
\text { membatasi, hal } \\
\text { yang dianalisis } \\
\text { adalah kode; }\end{array}$ & 2. & $\begin{array}{l}\text { Analisis } \\
\text { penggunaan } \\
\text { bahasa } \\
\text { diutamakan } \\
\text { daripada analisis } \\
\text { kode-kode; } \\
\text { organisasi }\end{array}$ \\
\hline
\end{tabular}

\begin{tabular}{|c|c|c|c|}
\hline & $\begin{array}{l}\text { analisis kode } \\
\text { lebih diutamakan } \\
\text { daripada analisis } \\
\text { penggunaan. }\end{array}$ & & $\begin{array}{l}\text { penggunaan } \\
\text { menyingkap } \\
\text { hubungan dan } \\
\text { cirri tambahan; } \\
\text { menjelaskan kode } \\
\text { dan penggunaan } \\
\text { dalam hubungan } \\
\text { integral } \\
\text { (dialektik). }\end{array}$ \\
\hline 3. & $\begin{array}{l}\text { Fungsi } \\
\text { referensial; } \\
\text { sepenuhnya } \\
\text { menggunakan } \\
\text { semantik sebagai } \\
\text { norma. }\end{array}$ & 3. & $\begin{array}{l}\text { Keseluruhannya } \\
\text { merupakan fungsi } \\
\text { sosial dan gaya } \\
\text { bahasa. }\end{array}$ \\
\hline 4. & \begin{tabular}{lr}
\multicolumn{2}{l}{ Elemen-elemen } \\
dan & struktur \\
analitis bersifat \\
arbitrer (menurut \\
pandangan \\
histories r atau \\
lintas budaya) \\
atau bersifat \\
semesta (menurut \\
pandangan \\
teoretis).
\end{tabular} & 4. & \begin{tabular}{lr}
\multicolumn{2}{l}{ Elemen-elemen } \\
dan & struktur- \\
struktur & bahasa \\
dianggap sebagai \\
kecocokan \\
etnografi (dari \\
segi psikiatris \\
dalam pengertian \\
Sapir).
\end{tabular} \\
\hline 5. & $\begin{array}{l}\text { Kesamaan } \\
\text { fungsional dari } \\
\text { (adaptif) } \\
\text { bahasa-bahasa; } \\
\text { semua bahasa } \\
\text { pada dasarnya } \\
\text { sama. }\end{array}$ & 5. & $\begin{array}{l}\text { Perbedaan } \\
\text { fungsional } \\
\text { (adaptif) dari } \\
\text { bahasa-bahasa, } \\
\text { varietas, gaya } \\
\text { bahasa, dan pada } \\
\text { dasarnya belum } \\
\text { tentu sama. }\end{array}$ \\
\hline 6. & $\begin{array}{l}\text { Satur komunitas } \\
\text { dan } \\
\text { homogeny } \\
\text { (replikasi } \\
\text { keseragaman). }\end{array}$ & 6. & $\begin{array}{l}\text { Masyarakat tutur } \\
\text { sebagai matriks } \\
\text { repertoar-kode, } \\
\text { atau gaya tutur } \\
\text { yang berbeda } \\
\text { (organisasi } \\
\text { keragaman). }\end{array}$ \\
\hline 7. & \begin{tabular}{lr}
\multicolumn{2}{l}{ Konsep-konsep } \\
dasar & seperti \\
masyarakat & tutur, \\
tindak & tutur, \\
penutur & yang \\
lancer, fungsi \\
ujaran dan bahasa \\
diterima \\
adanya apa \\
dipostulatkan apa \\
adanya.
\end{tabular} & 7. & $\begin{array}{l}\text { Konsep-konsep } \\
\text { dasar dianggap } \\
\text { sebagai } \\
\text { problematik dan } \\
\text { harus diteliti. }\end{array}$ \\
\hline
\end{tabular}

Mengkaji wacana secara sungguh-sungguh dapat mengungkapkan tingkat pemerolehan kompetensi komunikatif. Selain itu, bahasa digunakan dalam percakapan, salah satunya adalah wacana alamiah, yang merupakan data bahasa yang sangat penting. Fillmore dalam Tannen (1986:6) menyatakan bahwa bahasa yang digunakan dalam percakapan tatap muka termasuk penggunaan bahasa yang mendasar dan utama sehingga dapat digunakan untuk mendeskripsikan penyimpangan kaidah penggunaan aturan bahasa. Oleh sebab itu, analisis wacana percakapan dapat dikatakan 


\section{Vol. 3 No. 1 Februari 2019}

sebagai usaha untuk memahami bahasa dan pemakainya.

\section{Penggunaan Bahasa Dalam Perspektif Tindak Tutur}

Tindak tutur atau dalam bahasa Inggris disebut speech act merupakan aktivitas mengujarkan atau menuturkan tuturan dengan maksud tertentu. Austin dan Searle dalam Schiffrin (1994:63) mengatakan bahwa tindak tutur digunakan untuk melakukan tindakan sehingga bahasa dihubungkan dengan makna dan tindakan. Rasionalitas munculnya istilah tindak tutur adalah penutur tidak semata-mata mengatakan sesuatu dengan mengucapkan ekspresi saja. Dalam pengucapan ekspresi itu penutur juga melakukan tindakan sesuatu. Dengan mengacu pendapat para ahli, Gunarwan (1994:43) menyatakan bahwa mengujarkan sebuah tuturan dapat dilihat sebagai hal melakukan tindakan, di samping memang mengucapkan tuturan itu.

Demikianlah aktivitas mengujarkan atau menuturkan tuturan dengan maksud tertentu itu merupakan tindak tutur atau tindak ujar. Sehubungan dengan pengertian tindak tutur, Searle dalam Schiffrin (1994:75) berpendapat bahwa taksonomi Austin tidak berdasar pada prinsip taksonomi. Searle mengelompokkan tindak tutur menjadi lima jenis yang dirinci sebagai berikut.

1) Representatif adalah tindak tutur yang mengikat penuturnya kepada kebenaran atas apa yang dikatakannya (misalnya: menyatakan, melaporkan, menunjukkan, dan menyebutkan).

2) Direktif adalah tindak ujar yang dilakukan penuturnya dengan maksud agar si pendengar melakukan tindakan yang disebutkan dalam ujaran itu (misalnya: menyuruh, memohon, menuntut, menyarankan, dan menantang).

3) Ekspresif adalah tindak ujar yang dilakukan dengan maksud agar ujarannya diartikan sebagai evaluasi tentang hal yang disebutkan di dalam ujaran itu (misalnya: memuji, mengucapkan terima kasih, mengkritik, dan mengeluh).

4) Komisif adalah tindak ujaran yang mengikat penuturnya untuk melaksanakan apa yang disebutkan di dalam ujarannya (misalnya: berjanji, bersumpah, dan mengancam).

5) Deklarasi adalah tindak ujar yang dilakukan si penutur dengan maksud untuk menciptakan hal (status, keadaan, dan sebagainya) yang baru (misalnya: memutuskan, membatalkan, melarang, mengizinkan, dan memberi maaf).

Teori tindak tutur tersebut merupakan satu bentuk ujaran yang dapat mempunyai lebih dari satu fungsi. Kebalikan dari kenyataan bahwa satu bentuk ujaran dapat mempunyai lebih dari satu fungsi adalah kenyataan di dalam komunikasi yang sebenarnya bahwa satu fungsi dapat dinyatakan, dilayani, atau diutarakan dalam berbagai bentuk tuturan. Misalnya "permintaan", dapat diungkapkan dengan menggunakan bentuk ujaran yang berlainan seperti berikut ini. 1) Tuturan bermodus imperatif, tuturan ini misalnya: "Kerjakan tugas ini Ina!" 2) Tuturan bermodus eksplisit, tuturan ini misalnya: "Ibu minta mengerjakan tugas ini." 3) Tuturan bermodus performatif berpagar, tuturan ini misalnya: "Ibu sebenarnya mau minta Ina mengerjakan tugas ini." 4) Tuturan bermodus pernyataan keharusan, tuturan ini misalnya: "Kamu harus mengerjakan tugas ini." 5) Tuturan bermodus pernyataan keinginan, tuturan ini misalnya: "Ibu ingin tugas ini dikerjakan." 6) Tuturan bermodus rumusan saran, tuturan ini misalnya: "Bagaimana kalau tugas ini dikerjakan." 7) Tuturan bermodus persiapan pertanyaan, tuturan ini misalnya: "Kamu dapat mengerjakan tugas ini?" 8) Tuturan bermodus isyarat kuat, tuturan ini misalnya: "Dengan tugas ini selesai, menurut Ibu kamu bisa segera pulang." 9) Tuturan bermodus isyarat halus, tuturan ini misalnya: "Pertanyan di buku ini belum terjawab." Contoh dari kasus diatas merupakan jenis tindakan direktif yang merupakan tindak tutur yang mendorong mitra tutur melakukan sesuatu. Hal ini sering dijumpai dalam lingkungan sosial seperti di sekolah, di rumah, dan sebagainya.

\section{Implikasi Bagi Pendidikan Literasi}

Literasi yang dalam bahasa Inggrisnya Literacy berasal dari bahasa Latin littera (huruf) yang pengertiannya melibatkan penguasaan sistemsistem tulisan dan konvensi-konvensi yang menyertainya. Kendatipun demikian, literasi utamanya berhubungan dengan bahasa dan bagaimana bahasa itu digunakan. Adapun sistem bahasa tulis itu sifatnya sekunder. Manakala berbicara mengenai bahasa, tentunya tidak lepas dari pembicaraan mengenai budaya karena bahasa itu sendiri merupakan bagian dari budaya. Sehingga, pendefinisian istilah literasi tentunya harus mencakup unsur yang melingkupi bahasa itu sendiri, yakni situasi sosial budayanya.

Menurut Kern (2000) Literasi adalah penggunaan praktik-praktik situasi sosial, dan historis, serta kultural dalam menciptakan dan menginterpretasikan makna melalui teks. Literasi memerlukan setidaknya sebuah kepekaan tentang hubungan-hubungan antara konvensi-konvensi tekstual dan konteks penggunaanya serta idealnya kemampuan untuk berefleksi secara kritis tentang hubungan-hubungan itu. Karena peka dengan maksud dan tujuan, literasi itu bersifat dinamis, tidak statis, dan dapat bervariasi di antara komunitas dan kultur wacana. Literasi memerlukan serangkaian kemampuan kognitif, pengetahuan bahasa tulis dan lisan, pengetahuan tentang genre, dan pengetahuan kultural.

Terdapat tujuh prinsip pendidikan literasi yang diambil dari definisi Kern (2000) di atas, yaitu: 
a. Literasi melibatkan interpretasi

Penulis atau pembicara dan pembaca atau pendengar berpartisipasi dalam tindak interpretasi, yakni: penulis/pembicara menginterpretasikan dunia (peristiwa, pengalaman, gagasan, perasaan, dan lainlain), dan pembaca atau pendengar kemudian mengiterpretasikan interpretasi penulis/pembicara dalam bentuk konsepsinya sendiri tentang dunia.

b. Literasi melibatkan kolaborasi

Terdapat kerjasama antara dua pihak yakni penulis/pembicara dan pembaca/pendengar. Kerjasama yang dimaksud itu dalam upaya mencapai suatu pemahaman bersama. Penulis atau pembicara memutuskan apa yang harus ditulis/dikatakan atau yang tidak perlu ditulis atau dikatakan berdasarkan pemahaman mereka terhadap pembaca/pendengarnya. Sementara pembaca/pendengar mencurahkan motivasi, pengetahuan, dan pengalaman mereka agar dapat membuat teks penulis bermakna.

c. Literasi melibatkan konvensi

Orang-orang membaca dan menulis atau menyimak dan berbicara itu ditentukan oleh konvensi/kesepakatan kultural (tidak universal) yang berkembang melalui penggunaan dan dimodifikasi untuk tujuan-tujuan individual. Konvensi disini mencakup aturan-aturan bahasa baik lisan maupun tertulis.

d. Literasi melibatkan pengetahuan kultural Membaca dan menulis atau menyimak dan berbicara berfungsi dalam system sistem sikap, keyakinan, kebiasaan, cita-cita, dan nilai tertentu. Sehingga orang orang yang berada di luar suatu sistem budaya itu beresiko salah dipahami oleh orang-orang yang berada dalam sistem budaya tersebut.

e. Literasi melibatkan pemecahan masalah

Karena kata-kata selalu melekat pada konteks linguistik dan situasi yang melingkupinya, maka tindak menyimak, berbicara, membaca, dan menulis itu melibatkan upaya membayangkan hubungan-hubungan di antara kata-kata, frase-frase, kalimat-kalimat, unit-unit makna, teks-teks, dan dunia-dunia. Sebagai upaya memikirkan suatu bentuk pemecahan masalah.

f. Literasi melibatkan refleksi dan refleksi diri

Pembaca atau pendengar dan penulis atau pembicara memikirkan bahasa dan hubungan hubungannya dengan dunia dan diri mereka sendiri. Setelah mereka berada dalam situasi komunikasi mereka memikirkan apa yang telah mereka katakan, bagaimana mengatakannya, dan mengapa mengatakan hal tersebut.

g. Literasi melibatkan penggunaan bahasa

Literasi tidaklah sebatas pada sistemsistem bahasa lisan ataupun tulisan, melainkan mensyaratkan pengetahuan tentang bagaimana bahasa itu digunakan baik dalam konteks lisan maupun tertulis untuk menciptakan sebuah wacana.

Literasi tidaklah seragam karena literasi memiliki tingkatan-tingkatan yang menanjak. Jika seseorang sudah menguasai satu tahapan literasi maka ia memiliki pijakan untuk naik ke tingkatan literasi berikutnya. Wells (1987) menyebutkan bahwa terdapat empat tingkatan literasi, yaitu: performative, functional, informational, dan epistemic. Orang yang tingkat literasinya berada pada tingkat performative, ia mampu membaca dan menulis, serta berbicara dengan simbol-simbol yang digunakan bahasa. Pada tingkat functional orang diharapkan dapat menggunakan bahasa untuk memenuhi kehidupan sehari-hari seperti membaca buku manual. Pada tingkat informational orang diharapkan dapat mengakses pengetahuan dengan bahasa. Sementara pada tingkat epistemic orang dapat mentransformasikan pengetahuan dalam bahasa.

Kern (2000) memberikan ciri-ciri pembelajaran dengan kombinasi "tiga R", yakni Responding, Revising, dan Reflecting. Pada Responding melibatkan kedua belah pihak, baik guru maupun siswa. Para siswa memberi respon pada tugas-tugas yang diberikan guru atau pada teks-teks yang mereka baca. Demikian pula guru memberi respon pada jawaban-jawaban siswa agar mereka dapat mencapai tingkat 'kebenaran' yang diharapkan. Pemberian respon atas hasil pekerjaan siswa juga cukup penting agar mereka tahu apakah mereka sudah mencapai hal yang dirahapkan atau belum.

Revision yang dimaksud disini mencakup berbagai aktivitas berbahasa. Misalnya, dalam menyusun sebuah laporan kegiatan, revisi dapat dilaksanakan pada tataran perumusan gagasan, proses penyusunan, dan laporan yang tersusun. Reflecting berkenaan dengan evaluasi terhadap apa yang sudah dilakukan, apa yang dilihat, dan apa yang dirasakan ketika pembelajaran dilaksanakan. Secara spesifik lagi, refleksi dapat dibagi ke dalam dua, yaitu: dari sudut pandang bahasa reseptif (mendengarkan dan membaca) dan sudut pandang bahasa ekspresif (berbicara dan menulis). Dari sudut pandang bahasa reseptif beberapa pertanyaan dapat diajukan, yaitu: apa tujuan atau maksud penutur atau penulis ini? Apakah hal-hal tertentu yang menyiratkan keyakinan dan sikap pembicara atau penulis mengenai topik pembicaraan? dan lain-lain. Dari sudut pandang bahasa ekspresif, pertanyaan pertanyaan berikut ini cukup bermanfaat, yaitu: bagaimana orang lain 


\section{JURNAL TAMBORA}

Vol. 3 No. 1 Februari 2019

menginterpretasikan apa yang saya katakan? Dari mana saya tahu pendengar atau pembaca memahami atau meyakini apa yang saya kemukakan? dan sebagainya.

Penggunaan bahasa dalam berkomunikasi tindak tutur di sekolah khususnya dalam pendidikan literasi sangat erat hubungannya di dunia pendidikan. Kurikulum 2013 memusatkan pembelajaran yang aktif bagi siswa atau peserta didik, dan kontribusi guru sebagai fasilisator menjadikan pembelajaran bisa bermanfaat sepanjang hayat.

\section{PENUTUP}

\section{Kesimpulan}

Ketika seseorang menggunakan bahasanya, acapkali orang lain dapat menduga tentang kebangsaan atau identitas kelompok dari masyarakat tuturnya. Telah dikemukakan bahwa hal itu dimungkinkan karena penutur itu bertumbuhkembang dan dibentuk oleh bahasa sebagai bagian dari budaya masyarakatnya. Berbagai fenomena kebahasaan meliputi unsur linguistik (yakni bunyi, leksikon dan unsur gramatikal), unsur paralinguistik (seperti kecepatan, ekspresi wajah dan gerak tangan), unsur non-linguistik (seperti kondisi psikologis atau fisik penutur) dan lingkup budayanya akan muncul saling berkaitan ketika bahasa dipergunakan dalam berkomunikasi. Ketika terjadi realisasi penggunaan bahasa dalam komunikasi tersebut, keterkaitan antara bahasa, tindakan dan latar pengetahuan penutur tidak dapat dipisahkan.

Literasi tidak terpisahkan dari dunia pendidikan. Literasi menjadi sarana peserta didik dalam mengenal, memahami, dan menerapkan ilmu yang didapatkannya di bangku sekolah. Literasi juga terkait dengan kehidupan peserta didik, baik di rumah maupun di lingkungan sekitarnya. Mengacu pada metode pembelajaran Kurikulum 2013 yang menempatkan peserta didik sebagai subjek pembelajaran dan guru sebagai fasilitator, kegiatan literasi tidak lagi berfokus pada peserta didik semata. Guru, selain sebagai fasilitator, juga menjadi subjek pembelajaran. Akses yang luas pada sumber informasi, baik di dunia nyata maupun dunia maya dapat menjadikan peserta didik lebih tahu daripada guru. Oleh sebab itu, kegiatan peserta didik dalam berliterasi semestinya tidak lepas dari kontribusi guru, dan guru sebaiknya berupaya menjadi fasilitator yang berkualitas.

Terdapat tujuh unsur yang membentuk pengertian literasi, yaitu: interpretasi, kolaborasi, konvensi, pengetahuan kultural, pemecahan masalah, refleksi, dan penggunaan bahasa. Terdapat empat tingkatan literasi, yaitu: performative, functional, informational, dan epistemic. Responding, Revising, dan Reflecting adalah tiga ciri dari pembelajaran literasi. Teoriteori belajar yang mencakup teori belajar kognitif, teori belajar "Zone of Proximal Development Vigotsky, dan Scaffolding Talk and Routin Bruner" merupakan pegangan yang kokoh bagi para pendidik untuk melaksanakan pembelajaran literasi.

\section{REFERENSI}

Brown, Gillian and Yule, George. 1983. Analisis Wacana. Terjemahan oleh I. Soetikno, 1996. Jakarta: Gramedia.

Brown, H. Douglas. Tanpa Tahun. Prinsip Pembelajaran dan Pengajaran Bahasa, Edisi Kelima. Terjemahan oleh Noor Cholis dan Yusi Avianto Pareanom, 2007. Pearson Education, Inc.

Dinneen, Francis P., S.J. 1967. An Introduction to General Linguistics. New York: Holt Rinehart \& Winston, Inc.

Gunarwan, Asim. 1994. Pragmatik: Pandangan Mata Burung. Jakarta: Universitas Indonesia.

Kern, R. 2000. Literacy and Language Teaching. Oxford: Oxford University Press.

Richard, Jack C. 1995. Tentang Percakapan. Terjemahan Ismari. Surabaya: Airlangga university Press.

Schiffrin, Deborah. 1994. Ancangan Kajian Wacana. Terjemahan oleh Unang, dkk, 2007. Yogyakarta: Pustaka Pelajar.

Tannen, Deborah. 1986. Conversational Style: Analyzing Talk Among Friends. New Jersey: Ablex Pub. Co.

Wells, B. 1987. Apprenticeship in Literacy .dalam Interchange 18,1 (2):109-123.

Zahari, Musril. 2011. Menjunjung Bahasa Persatuan: Sebuah Kumpulan Karangan. Jakarta: Metros Pos. 